Arab Univ. J. Agric. Sci., Ain Shams Univ., Cairo, 13(3), 1033 - 1046, 2005

\title{
MITES IN MARJORAM AND CHAMOMILE CULTIVATIONS IN FAYOUM AND THE RELATIVE ABUNDANCE OF TWENTY SIX SPECIES
}

[71]

\author{
Rahil' ${ }^{1}$, A.A.R.
}

\begin{abstract}
A study on mite species in marjoram and chamomile plantations in Fayoum was carried out during 2003 and 2004 seasons. Twenty-six species were found and divided according to their feeding habits into three major groups, phytophagous ( 7 species), predaceous ( 8 species) and a group of debatable feeding habits (11 species). Population density evaluation showed that Tetranychus urticae Koch was the main phytophagous mite on both hosts. The predatory mite Amblyseius cydnodactylon Shehata and Zaher was dominant on marjoram followed by Hemicheyletia bakeri (Ehara). From the debatable group, Pronematus ubiquitus Mc Gregor was the dominant followed by Tyrophagus putrescentiae (Schrank) and Paralorryia gizai El-Bagoury. On chamomile, the predatory mite Eupodes niloticus Abou-Awad \& El-Bagoury was dominant and from the debatable group, Tydeus kochi Oud. was dominant followed by $T$. putrescentiae and $P$. gizai. Population densities were insignificantly affected by temperature and relative humidity.
\end{abstract}

Key words: Marjoram mites; Chamomile mites; Mite population

\section{INTRODUCTION}

In recent years, aromatic and medicinal plants attracted more attention and became of increased economic importance in Egypt as export agricultural products used in various pharmaceutical therapeutic purposes. Thus, there has been a considerable expansion in cultivation of these crops, which reached to about 15000 feddans during 2005 in Fayoum alone. Almost $78 \%$ of this area is cultivated with Marjoram, Majorana hortensis and chamomile, Matricaria chamomilla. As pointed out by Rakova, 1961 and Crale et al 1989, these plants are the main source of highly aromatic essential oils.

Mite species associated with these crops fall into three main categories, a) phytophagous, b) predaceous, and c)of other feeding habits or debatable. Tetranychus cinnabarinus was reported by Harakly (1974) on Capsicum minimum. T. arabicus (urticae) was reported by Mesbah et al (1983 a) on Mentha piperita, Pelargonium graveolens, Rosemurinus officinalis,

1- Plant Protection Dept., Fac., of Agric., Cairo Univ., El-Fayoum Branch, Egypt 
Arab Univ. J. Agric. Sci., Ain Shams Univ., Cairo, 13(3), 1033 - 1046, 2005

Cucurbita sp. and Rosa sp.; also Brevipalpus obovatus Donn. on $M$. piperita, Ocimum basilicum, O. kilimand scharicum and Thymus vulgaris, and the predatory mite Amblyseius rubini Swirski \& Amitai on M. piperita, $O$. basilicum, R. officinalis and Vinca rosae. Mesbah et al (1983b) found A. rubini on Hibiscus sabdarifa. Nagy and Tetenyi (1986) also reported T. urticae on Mentha spp. and found a gall-forming mite (not identified) associated with Carum carvi. Gupta, (1990) found Petrobia latens on Cuminum cyminum in India. Krips et al (1996) mentioned that T. urticae is an important pest of Gerbera jamesonii. Petanovic et al (2000) reported the eriophyid mite Aceria matricariae associated with Matricaria chamomilla in Serbia.

However, studies on species and densities of population of mites on marjoram and chamomile are few, and more information is needed in this respect. Therefore, the objective of the present study was to survey mite species associated with these two crops and to evaluate the population of each species throughout two successive years.

\section{MATERIAL AND METHODS}

This study was carried out at the farm of the Faculty of Agriculture, El-Fayoum during two successive years; 2003 and 2004. Marjoram and chamomile were transplanted (one plant per hill) in December, each in an area of $1 / 4$ feddan, divided into 16 equal plots. The usual agricultural practices were followed, except for pest control.
Twenty plants were biweekly picked at random, starting two weeks after transplantion. For marjoram, sampling continued from January 2003 to December 2004. For chamomile sampling continued from January to May each year. Direct examination was made in the laboratory under a stereomicroscope. Mites found were counted and enough specimens were mounted in Hoyer's medium for identified.

Taxonomy systems and keys given by Hughes, 1961; McDaniel, 1979 and Zaher, 1986 were the basis for identification of species. Population data for T. urticae was statistically treated using the simple correlation with weather conditions (average temp. and R.H.).

\section{RESULTS AND DISCUSSION}

I- Survey: Mites found on marjoram and chamomile were identified as follows:

1- Family: Tetranychidae; Tetranychus urticae Koch; Eutetranychus orientalis Klein; Aponychus imperatus Hafez and ElBadry; Petrobia lycopersici Zaher, Gomaa and El-Enany and Oligonychus punicae (Hirst).

2- Family: Tenuipalpidae; Brevipalpus obovatus Donn. and Phyllotetranychus aegyptiacus Sayed.

3- Family: Phytoseiidae; Euseius scutalis, Athias \& Henriot; Amblyseius cydnodactylon Shehata and Zaher; $A$.

1- Plant Protection Dept., Fac., of Agric., Cairo Univ., El-Fayoum Branch, Egypt 
1035

Mites in Fayoum, Egypt

longispinosus (Evans) and

Typhlodromus athiasae $(=T$. pelargonicus El-Badry).

4- Family: Bdellidae; Spinibdella bifurcata Atyeo.

5- Family: Cheyletidae; Hemicheyletia bakeri (Ehara)

6- Family: Eupodidae; Eupodes niloticus Abou-Awad \& ElBagoury

7- Family: Stigmaeidae; Agistemus exsertus Gonz.

8- Family: Tydeidae; Pronematus ubiquitus Mc Gregor; Tydeus kochi Oud.; Paralorryia gizai ElBagoury and P.mali Oud.

9- Family: Acaridae; Tyrophagus putrescentiae (Schrank); Caloglyphus berlesei (Mich.); Aleuroglyphus ovatus (Troup.) and Rhizoglyphus robini Claparede.

10- Family: Glycyphagidae; Glycyphagus destructor (Schrank).

11- Family: Ctenoglaphidae; Ctenoglyphus plumiger (Koch).

12-Family: Pyroglyphidae; Dermatophagoides farinae Hughes

These 26 mite species could be classified, according to their feeding habits and to plant in association with, as follows:

\section{A- Species found only on marjoram}

1. Phytophagous mites
Five species; T. urticae; E. orientalis; $A$. imperatus; B.obovatus and $P$. aegyptiacus.

\section{Predaceous mites}

Six species; E. scutalis; $A$. cydnodactylon; A. longispinosus, $H$. bakeri, S. bifurcata and A. exsertus.

\section{Mites of debatable feeding habits}

Six species; T. kochi; P. ubiquitus; P. gizai; T. putrescentiae; $G$. destructor and C. berlesei.

B- Species found only on chamomile

\section{Phytophagous mites}

Four species; T.urticae; O. punicae; $P$. lycopersic and B. obovatus .

\section{Predaceous mites}

Three species; A. cydnodactylon, $T$. pelargonicus and E. niloticus .

\section{Mites of debatable feeding habits}

Nine species; T. kochi; P. ubiquitus; $P$. gizai; P. mali; $T$. putrescentiae; $R$. robini; $C$. plumiger; $A$. ovatus and $D$. farinae.

\section{C-Species found on both marjoram and chamomile}

\section{Phytophagous mites}

Two species; T. urticae and $B$. obovatus.

\section{Predaceous mites}

One species; A. cydnodactylon.

3. Mites of debatable feeding habits 
Four species; $T$. putrescentiae; $P$. ubiquitus; T. kochi and P. gizai .

II- Relative abundance of the most populated species collected

\section{A) On marjoram}

a-During 2003 (Table, 1)

\section{1) Tetranychus urticae}

This phytophogous species was the main mite pest found on marjoram allover the year, the highest densities occurred in May and September with 99 and 92 individuals /40 plants at average 
1033

Arab Univ. J. Agric. Sci., Ain Shams Univ., Cairo, 13(3), 1033 - 1046, 2005

1- Plant Protection Dept., Fac., of Agric., Cairo Univ., El-Fayoum Branch, Egypt

(Received May 12, 2005)

(Accepted June 4, 2005) 
Arab Univ. J. Agric. Sci., Ain Shams Univ., Cairo, 13(3), 1033 - 1046, 2005

temperature 29.4 and $29.0^{\circ} \mathrm{C}$ with 50 and $58 \% \mathrm{RH}$, respectively. The lowest densities ( 7 and 8 individuals/40 plants) were recorded during June and July at average temperature 31.3 and $31.7^{\circ} \mathrm{C}$ with 53 and $55 \% \mathrm{RH}$, respectively.

A positive insignificant correlation was found between population and temperature $(\mathrm{r}=0.242)$, whereas the relationship with humidity was negatively insignificant $(\mathrm{r}=-0.393)$.

According to Mesbah et al (1983 a) T. arabicus (urticae) had two peaks on rosemary during the first half of June and the second half of July. The highest population was recorded on rose during June, while on geranium the numbers were extremely low allover the growing season.

\section{Amblyseius cydnodactylon}

This predatory mite was the most abundant. The population density began with two individuals /40 plants in March and increased to 7 individuals in April, then fluctuated till reaching a peak in October (12 individuals/40 plants).

\section{Hemicheyletia bakeri}

This predator was mostly found during the period from September, 2003 till February 2004 with successive monthly count of $2,10,8,22,12$, and 8 individuals / 40 plants at respective average temperatures $29.2,26.2,21.6$, $15.9,15.1$ and $16.2^{\circ} \mathrm{C}$ with respective $\mathrm{RH}$ $58,59,63,58,52$ and $59 \%$.

\section{Tyrophagus putrescentiae}

This acarid mite, surpassed in number the other species of debatable feeding habits. The highest population was during November (25 individuals/40 plants).

\section{Pronematus ubiquitus and $\boldsymbol{P}$. gizai}

These mites of debatable feeding habits were second in population to $T$. putrescentiae with a total number of 23 and 21 / 40 plants, respectively.

\section{b- During 2004 year (Table, 2)}

\section{T. urticae}

The highest numbers, 62, 59, 77 and 63 individuals $/ 40$ plants, were recorded during January, February, April and July at average temperatures $15.1,16.2,30.1$ and $21.4{ }^{\circ} \mathrm{C}$ with $59,60,52$ and $51 \% \mathrm{RH}$, respectively. The lowest numbers, $6,7,6$ individuals $/ 40$ plants, were recorded in September, November and December, at average temperature $26.6,21.2$ and $16.3^{\circ} \mathrm{C}$ with 53,62 and $60 \mathrm{RH} \%$, respectively.

A negative insignificant correlation was found between these numbers and both temperature $(\mathrm{r}=-0.137)$ and $\mathrm{RH} \%$ $(\mathrm{r}=-0.219)$.

\section{A. cydnodactylon}

The highest number was recorded in January (11 individuals /40 plants), decreased sharply in February 4 individuals/40 plants, disappeared during March and April, then later these numbers 6, 4, 2 individuals/40 plants, were found during May, June and July, respectively. Thereafter, only two individuals were found in September.

1- Plant Protection Dept., Fac., of Agric., Cairo Univ., El-Fayoum Branch, Egypt 


\section{P. ubiquitus}

This tydeid mite, was abundant in September with population reaching 107 individuals / 40 plants although it did not exceed 6 individuals / 40 plants throughout survey. 
Rahil

Arab Univ. J. Agric. Sci., 13(3), 2005 


\section{Other species of debatable feeding habits}

P. gizai; T. putrescentiae; $G$. destructor; T. kochi and C. berlesei were found in considerable numbers reaching $80,77,75,64$ and 7 individuals, respectively as a total numbers during the year.

\section{B- On chamomile (Table, 3)}

\section{a- During 2003}

\section{T. urticae}

This species was the main mite pest found on chamomile .None of this mite could be observed during January. The population density began with 4 individuals / 40 plants in February at average temperature $15.4^{\circ} \mathrm{C}$ with 58 $\% \mathrm{RH}$, then it gradually increased till reaching its peak in April (86 individuals / 40 plants) at average temperature $21.8^{\circ} \mathrm{C}$ and $56 \%$ RH. After this peak, decreased sharply to 11 individuals/40 plants in May at average temperature $26.8^{\circ} \mathrm{C}$ with $51 \% \mathrm{RH}$.

A positive insignificant correlation was found between population and temperature $(\mathrm{r}=0.343)$, whereas the relationship with humidity was negatively insignificant $(r=-0.262)$.

\section{2) Eupodes niloticus}

The population of this mite fluctuated in few numbers to record 4 individuals / 40 plants in February, decreased in March and April ( 2 individuals / 40 plants for each), while none of this mite was recorded during January and May.

\section{3) Ctenoglyphus plumiger}

This species was found in January and February reaching 19 and 16 individuals and disappeared during April and May.

\section{Other species of debatable habits}

T. putrescentiae and T. kochi were found in considerable numbers reaching 39 and 33 individuals, respectively throughout survey.

\section{b- During 2004}

\section{T. urticae}

The population density gradually increased with the progress of the season till reaching its peak in May, the monthly collected numbers were $2,5,5,18,118$ individuals/40 plants from January to May at average temperatures $13.6,15$, $17.6,19.2$ and $23.6^{\circ} \mathrm{C}$ with $57,61,56,55$ and $48 \% \mathrm{RH}$, respectively.

From the above results, peak of $T$. urticae observed in April 2003, while in 2004, peak occurred in May.

The correlation between popoulation and temperature was positively insignificant ( $r=0.829$ ) whereas with R.H.\% was negatively significant $(\mathrm{r}=$ 0.900 ).

\section{E. niloticus}

More numbers of this species were found compared to that recorded during 2003. The highest number was recorded in February (15 individuals / 40 plants), decreased to 6 and 9 individuals / 40 plants in March and April, respectively.

\section{T. kochi}


Rahil

Less numbers of this species were 2003 , only 15 individuals/40 plants was found compared to that recorded during recorded in February. 
1033

Arab Univ. J. Agric. Sci., Ain Shams Univ., Cairo, 13(3), 1033 - 1046, 2005

1- Plant Protection Dept., Fac., of Agric., Cairo Univ., El-Fayoum Branch, Egypt

(Received May 12, 2005)

(Accepted June 4, 2005) 
Arab Univ. J. Agric. Sci., Ain Shams Univ., Cairo, 13(3), 1033 - 1046, 2005

\section{III- The relationship between populations of phytophagous and predaceous mites}

\section{a) On marjoram (Tables, 1-2 and Figs. 1-2 )}

In 2003, the number of phytophagous mites was generally low during January and February with a total of (9-10 individuals/ 40 plants). During this period no predaceous mites were found, the population density of phytophagous mites fluctuated normally with two peaks (May $\&$ September), meanwhile, the population of predaceous mites was relatively at low level until September (2-13 mites / 40 plants). Therefore, predation was ineffective against these mite pests, perhaps due to a high level of T. urticae mites compared to that of predators, besides the effect of weather conditions. By October, the phytophagous mites reach the lowest level whereas the number of predators found well exceeded the number of phytophagous.

On the contrary in 2004, high numbers of phytophagous and predaceous mites were collected during January and February to record $27 \& 12$ of predaceous mites correlated with $62 \& 59$ of phytophagous mites, respectively, then the population density of phytophagous mites increased gradually till April to record 58 and 77 individuals / 40 plants compared to low numbers of predator mites ( 3 individuals/40 plants in both March and April). Thereafter, the population density of phytophagous and predaceous mites fluctuated in the period from May to December, lately when the phytophagous mites reached to the lowest level (6 individuals), the predaceous mites reached to considerable numbers ( 5 individuals) during September.

b) On chamomile (Table, 3 and Figs. 3-4)

In 2003, one individual of phytophagous mites was found during January and no predaceous mites were observed during this month. In February to April a considerable numbers of predaceous mites were recorded and the ratios between predaceous to phytophagous mites reach to about $0.66: 1,1: 1$ and 1:5 during the mentioned period, respectively. Lately, 11 individuals of phytophagous mites only were found during May.

In 2004, the number of phytophagous mites was generally recorded allover the season. population density fluctuated during January, February and March, then increased during April and reach its peak in May. For predaceous mites the recorded numbers surpassed phytophagous during February \& March and occurred in considerable numbers in April.

From the previous results it could be stated that marjoram and chamomile inhabited 26 mite species. Seven species were recorded on both plants, 10 species were recorded on marjoram only and 9 on chamomile only. T. urticae was the main phytophagous mite but was more abundant on marjoram. The predaceous mite $A$. cydnodactylon was the only predator found on both plants and was also more abundant on marjoram. The cheyletid predator $H$. bakeri was

1- Plant Protection Dept., Fac., of Agric., Cairo Univ., El-Fayoum Branch, Egypt 
13

Mites in Fayoum, Egypt

observed in high numbers on marjoram

ubiquitus, T. putrescentiae and P. gizai especially during 2003, meanwhile, $E$. niloticus was more abundant on

chamomile than other predators. Of the species of debatable feeding habits, $P$. were recorded in high numbers on marjoram whereas $T$. kochi numbers surpassed each of $T$. putrescentiae and $P$. gizai on chamomile. 
1033

Arab Univ. J. Agric. Sci., Ain Shams Univ., Cairo, 13(3), 1033 - 1046, 2005

1- Plant Protection Dept., Fac., of Agric., Cairo Univ., El-Fayoum Branch, Egypt

(Received May 12, 2005)

(Accepted June 4, 2005) 
Mites in Fayoum, Egypt

Arab Univ. J. Agric. Sci., 13(3), 2005 
Arab Univ. J. Agric. Sci., Ain Shams Univ., Cairo, 13(3), 1033 - 1046, 2005

\section{REFERENCES}

\section{Crale, R.; B. Dolle and E. Reinkard}

(1989). An approach to the production of chamomile extracts. Planta Medica, 55(6): 540-543.

Gupta, B.M. (1990). Occurrence of brown wheat mite Petrobia latens (Muller) on cumin in Rajasthan. Indian Cocoa, Arecanut and Spices J., 13(4): 143-145.

Harakly, F.A. (1974). Preliminary survey of pests infesting solanaceous truk crops in Egypt. Bull. Soc. Entom. Egypt, 58: 133-140.

Hughes, A.M. (1961). The Mites of Stored Food 287pp. Min. of Agric., Fish. and Food. London.

Krips, O.E.; P.E.L. Willems and M. Dicke (1996). Suitability of the ornamental crop Gerbera jamesonii for spider mites and the attraction of predators in response to spider mite damage. OILB/SROP 19(5): 81-87. McDaniel, B. (1979). How to Know the Mites and Ticks 335 pp. Wm. C. Brown Co., Dubuque, Iowa.

Mesbah, H.A.; H.K. El-Sherif; K.S. Moursi and M.A. Mahmoud (1983a). Survey of the pests infesting medicinal and ornamental plants in Egypt III. The common harmful insects and mites found on eleven medicinal and ornamental plants at Alexandria district Proc. $5^{\text {th }}$ Arab Pesticide Conf. Tanta Univ., Egypt, IV: 107-119.

Mesbah, H.A.; K.S. Moursi; I.A. Abou El-Fadl and E.A. Zakzouk (1983b). Survey of the pests infesting medicinal and ornamental plants in Egypt. II. The common hurtful pests and beneficial ones found on roselle plants, Hibiscus subdarifa at Alexandria district. Proc. $5^{\text {th }}$ Arab Pesticide Conf. Tanta Univ., Egypt, IV: 91-106.

Nagy, F. and P. Tetenyi (1986). Modern and well integrated techniques for protecting some medicinal plants grown in Hungary. Parasitica, 42(1): 17-24. Petanovic, R.; J. Boczek and A. Shi (2000). Four new Aceria species.(Acari : Eriophyoidea) from Serbia. Acta Entom. Serbica, 5(1-2):119-129. Rakova, N.V. (1961). Changes of the assay of essential oil on storage of coriander seeds. Spiritovaya Prom., 27(5): 13-16.

Zaher, M.A. (1986). Survey and Ecological Studies on Phytophagous, Predaceous and Soil Mites in Egypt. Scientific Report. PL 480 Programme U.S.A. Fac. Agric. Cairo Univ., Egypt.

1- Plant Protection Dept., Fac., of Agric., Cairo Univ., El-Fayoum Branch, Egypt

(Received May 12, 2005)

(Accepted June 4, 2005) 
Arab Univ. J. Agric. Sci., Ain Shams Univ., Cairo, 13(3), 1033 - 1046, 2005

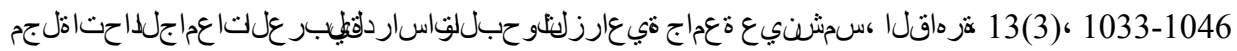
، 2005

\title{
Majorana hortensis

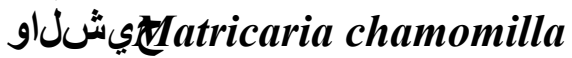

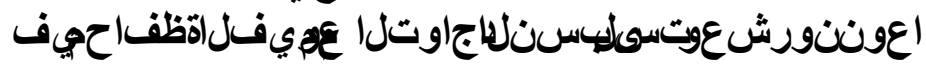

]71[

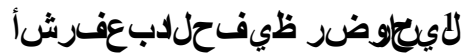

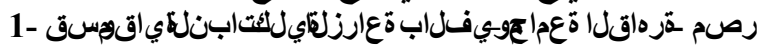

شوقدربلا : الوأ رثكأ نتيرطعلفيبطلابلتابنلطاعت

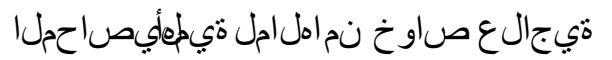

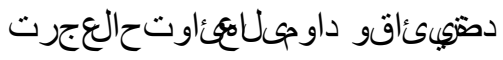

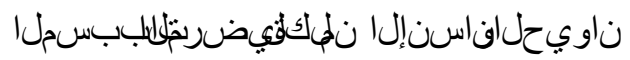

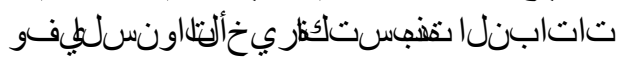

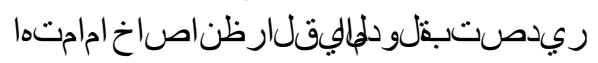

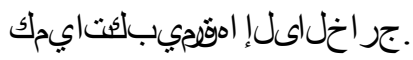

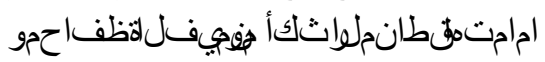

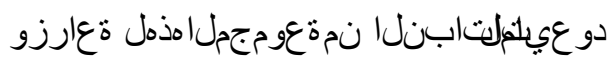

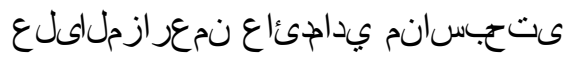

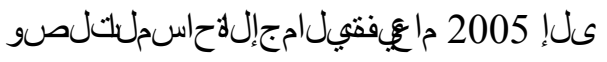

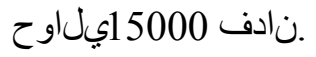

وة:ساردلا مذه نمفدهل ناناكاذل

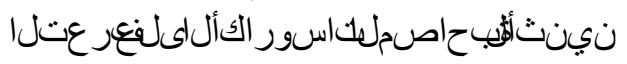

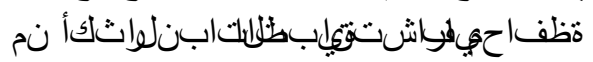

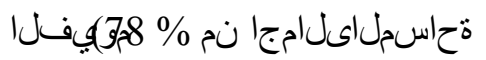

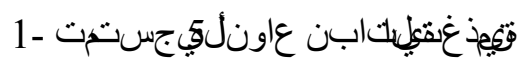

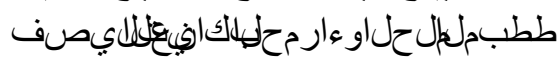

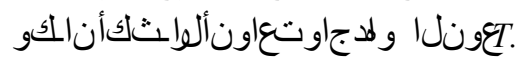

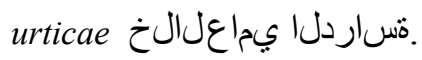

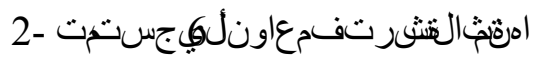

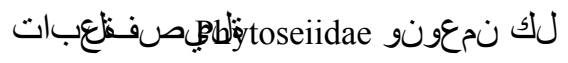

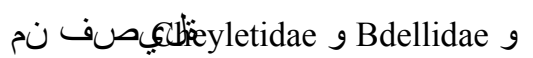
ادجاوتعاونأللاثك أناكو Stigmaeidae عونللم ادجاث H. bakeri .

3- نلفيذّت مبث T. putrescentiae .

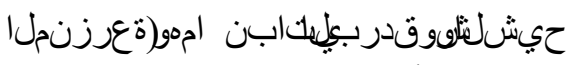

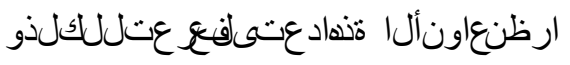

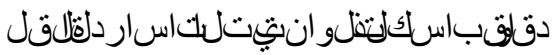
ييلياتساردلاتحضوات

حيشلائيناث

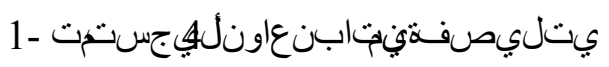

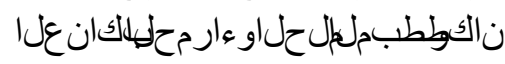
لالاخاشتناهرثكأ urticae قّنساردلايجمسوم

1- Plant Protection Dept., Fac., of Agric., Cairo Univ., El-Fayoum Branch, Egypt

(Received May 12, 2005)

(Accepted June 4, 2005) 
Arab Univ. J. Agric. Sci., Ain Shams Univ., Cairo, 13(3), 1033 - 1046, 2005

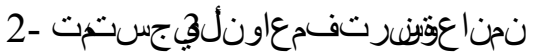

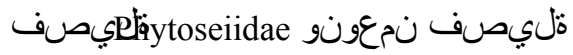

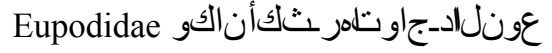

E. niloticus .

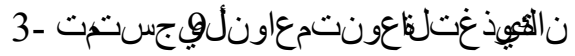

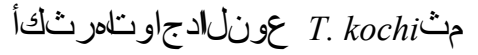
putrescentiae $T$.

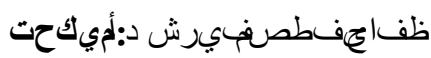

اننخ-يز عمرلكم د.أ

1- Plant Protection Dept., Fac., of Agric., Cairo Univ., El-Fayoum Branch, Egypt 